\title{
ФОРМУВАННЯ ПІЗНАВАЛЬНОЇ САМОСТІЙНОСТІ СТУДЕНТІВ У КОНТЕКСТІ БОЛОНСЬКОГО ПРОЦЕСУ
}

\author{
М. Ф. Шустваль ${ }^{1}$, С. М. Шустваль ${ }^{2}$, Т. І. Лядова ${ }^{2}$, О. В. Волобусва ${ }^{2}$ \\ ${ }^{1}$ Харківська медична академія післядипломної освіти, \\ ${ }^{2}$ Харківський національний університет імені В. Н. Каразіна
}

\section{FORMING OF PERCEPTIONAL INDEPENDENCE OF STUDENTS IN THE CONTEXT OF BOLOGNA PROCESS}

\author{
M. F. Shustval' ${ }^{1}$, S. M. Shustval ${ }^{2}$, T. I. Lyadova ${ }^{2}$, O. V. Volobuyeva ${ }^{2}$ \\ ${ }^{1}$ Kharkiv Medical Academy of Post-Graduate Education, \\ ${ }^{2}$ Kharkiv National University by V. N. Karazin
}

\begin{abstract}
Формування спеціалістів у вищих навчальних закладах полягає в тому, щоб максимально сприяти розвитку у студентів творчої ініціативи, вихованню потреби у самоосвіті, націленості на підвищення рівня свосї теоретичної підготовки, удосконалення вмінь і навичок самостійної роботи.
\end{abstract}

Education of specialists in higher educational establishments resides in the highest possible assistance in followed features development, but not limited by: creative initiative, private necessity of self-education, targeting of theoretical knowledge increase, unsupervised work skills and attainments improvement.

Вступ. Проблема виховання самостійності як складової соціальної зрілості особистості належить до однісї з найважливіших у теорії і практиці виховання й навчання. Самостійність характеризує особистість з точки зору іiі активності і свідомого самовираження у діяльності.

В умовах включення України до Болонського освітнього процесу гостро постає проблема організації та контролю самостійної роботи студентів. Самостійність, як відомо, $є$ найбільш істотною якістю людини як особистості та суб’ єкта діяльності.

Проблема самостійності мислення і діяльності студентів прямо пов'язана зі зміною парадигми системи сучасної освіти. Особливою рисою організації навчального процесу у вищих навчальних закладах України в сучасних умовах стає поступове збільшення навчального часу на самостійну роботу студентів. Навчати студентів самостійно поновлювати свої знання, самостійно орієнтуватись в стрімкому потоці нової інформації $€$ важливим завданням сучасної вищої школи. Від уміння студентів самостійно планувати, організовувати і контролювати процес навчання й пізнавальної діяльності залежить якість оволодіння ними знаннями, вміннями і навичками [1-5].

Основна частина. Мета статті - розглянути основні шляхи організації самостійної роботи студентів за рахунок побудови і проведення занять за принципом науковості, проблемності, професійного спрямування та здійснення системного контролю, спрямованих на формування у студентів творчих здібностей, наукового світогляду, професійних знань.

Суть пізнавальної самостійності виявляється в потребі й умінні студентів самостійно мислити, у здатності орієнтуватися в новій ситуації, самому бачити питання, задачі і знайти підхід до їх розв'язання. Пізнавальна самостійність виявляється в умовах в умінні самостійно аналізувати складні навчальні задачі і виконувати їх без сторонньої допомоги, що характеризується певною критичністю розуму студента, здатністю висловлювати свою думку незалежно від суджень інших. Самостійність у навчальній роботі студентів - це насамперед здатність не тільки розуміти матеріал, а й застосовувати його в нових видах самостійних завдань.

Розглядаючи самостійність як першорядну умову всебічного розвитку особистості студентів, можна виділити три види самостійності студентів: організаційно-технічну самостійність, самостійність у практичній діяльності, самостійність у процесі пізнавальної діяльності.

Пізнавальна активність і самостійність студента в навчальній роботі поняття взаємопов'язані, але не тотожні. У навчальній роботі самостійність вияв-

() М. Ф. Шустваль, С. М. Шустваль, Т. І. Лядова, О. В. Волобуєва 
ляється в активності, спрямованій на набування, вдосконалення знань, оволодіння прийомами роботи. Останнє пов' язане з формуванням пізнавальних інтересів та інших мотивів, які стимулюють і зміцнюють вольові зусилля для виконання тих чи інших завдань. Пізнавальна самостійність завжди спрямована на засвоєння нових знань, передбачає готовність студентів до пошукової роботи, а пізнавальна активність має місце як під час засвоєння знань, так i під час їх відтворення, закріплення. Пізнавальна самостійність співвідноситься 3 творчими здібностями як видове і родове поняття, але формування обох цих якостей можливе лише в процесі активної інтелектуальної діяльності. Пізнавальна активність і пізнавальна самостійність взаємопосилюють одна одну: в умовах мислительної активності виявляється самостійність студентів, яка є необхідним внутрішнім стимулом розвитку мислення. Але хоч ці сторони навчальної діяльності тісно пов'язані, кожна 3 них через специфічність виявів і формування є окремим предметом дослідження.

Отже, пізнавальна самостійність студентів формується не внаслідок дії якогось одного ефективного засобу, а є закономірним результатом досконалої системи навчання і виховання студентів, спрямованої на виборчий розвиток самостійності думки і самостійності як риси характеру студентів.

З позиції психологічної науки, самостійність розглядається як закріплене у навчальному досвіді генералізоване ставлення до вибору і реалізації моральних цінностей, засноване на внутрішніх стимулах i внутрішній саморегуляції, що виявляється упрагненні, вмінні, звичці розв' язувати конкретні питання і практичні завдання самостійно. Проявом самостійності $\epsilon$ вміння самостійно бачити суть поставлених перед ним завдань, виділяти основне в ньому, а також уміти його розв' язувати [4].

Самостійність як соціальна якість особистості характеризується здатністю людини зорієнтуватись, критично оцінити ситуацію, висловити свою точку зору з конкретного приводу.

Педагогічний аспект виховання самостійності $€$ процес переходу особистості від зовнішнього керівництва до саморегуляції, внутрішнього обгрунтування свого вчинку, лінії поведінки, до вільного вибору способів дій у процесі життєдіяльності студентів.

Самостійність характеризується двома факторами: по-перше, сукупністю засобів, знань, умінь і навичок, якими володіє особистість; по-друге, ставленням особистості до процесу діяльності, ііі результатів і умінь здійснення, а також зв' язками, які складають- ся у процесі діяльності з іншими людьми. Як соціальна якість, самостійність передбачає наявність активної життєвої позиції, організаторських якостей, готовності та здатності своїми силами здійснювати практичну діяльність, відповідально до неї ставитись, встановлювати певні стосунки в колективі [1].

Звідси виходить, що самостійність передбачає активність, ініціативність особистості до себе та до інших.

Зростаючий розрив між обсягом знань, призначених для вивчення й можливістю їх засвоєння, може бути подоланий, головним чином, шляхом розвитку розумових здібностей студентів, формування в них здатності самим регулювати процес засвоєння нових знань і підвищення ефективності навчання. Самостійність у навчальній діяльності зумовлена структурою планів вищих навчальних закладів, у яких значна частина навчального часу виділена на самостійну роботу студентів.

При обмеженні навчального аудиторного часу, а також $з$ урахуванням психологічних особливостей студентів й обов' язкової умови інтенсивності вивчення фахових дисциплін для оволодіння професійними вміннями і навичками, виникає необхідність навчати студентів самостійно працювати. Суперечність між рівнем знань студентів і їх умінням повноцінно використовувати їх у своїй професійній діяльності можна вирішити, використовуючи сучасні педагогічні технології, що створюють пріоритетні умови для самостійної пізнавальної діяльності й дають змогу значно підвищити ефективність навчального процесу.

Тому одним із головних резервів удосконалення навчального процесу у вузі $є$ більш широке використання творчого потенціалу студентів, впровадження методів і форм навчання, які передбачають активну самостійну роботу [1-4]. Саме самостійна робота студентів повинна стати однією із складових навчального процесу, оскільки вона має ряд цілей, серед яких слід виділити:

- виховні - прищеплення самостійності як риси особистості й стереотипу пізнання, тобто потреби до поповнення та оновлення своїх знань;

- навчальні - набуття вмінь і практичних навичок техніки самостійної роботи, уміння приймати рішення, формувати конкретні завдання залежно від загального напряму діяльності, уміння визначити методи і засоби розв'язання проблеми;

- освітні-здобування студентами загальноосвітніх, професійних умінь, знань, навичок.

Найбільш важливими є питання організації управління і контролю за самостійною роботою студентів. 
Відомо, що саме самостійна робота сприяє максимальному виявленню потенціалу студентів, формує вміння і навички використання та переробки інформації.

Студенти, які не володіють навичками самостійної підготовки, переважно не встигають відібрати головне у навчальній дисципліні, перестають іiі розуміти, втрачають впевненість у собі, у своїх можливостях. Саме в цьому часто полягає основна причина низького рівня знань багатьох студентів і втрати ними інтересу до навчання і обраної спеціальності.

Отже, формування спеціалістів у вузі повинно полягати в тому, щоб максимально сприяти розвитку у студентів творчої ініціативи, вихованню потреби у самоосвіті, націленості на підвищення рівня своєї теоретичної підготовки, до удосконалення вмінь і навичок самостійної роботи.

Вищевикладене свідчить про те, що підготовка студентів до самоосвіти вже з перших днів навчання у вузі $€$ актуальною соціально-педагогічною проблемою, від вирішення якої багато в чому буде залежати ефективність майбутньої діяльності спеціалістів різних галузей, оскільки найбільш складним етапом становлення особистості спеціаліста, в тому числі і набуття навичок самостійної роботи, ми вважаємо початок навчання у вузі, особливо перший курс, коли відбувається зміна в соціальному статусі особистості, структурі і змісті пізнавальної діяльності.

Організація самостійної роботи студентів $є$ динамічним процесом, в якому $є$ самостійна діяльність студентів, управління викладача та створення відповідних відносин між ними. В сучасний період виділяють чотири види самостійної роботи [2]:

1. За зразком, який використовує відомий спосіб розв'язання теоретичних і практичних завдань для аналогічних ситуацій і сприяє розвитку продуктивної навчально-пізнавальної діяльності. Такий вид самостійної роботи може розглядатися лише як основа пізнавальної самостійності.

2. Модифікація і використання відомого способу розв'язання завдань у незвичайній ситуації. В цьому випадку застосовуються способи продуктивності 3 перетворення і узагальнення теоретичних і практичних знань, які сприяють розвитку практичного мислення. Пізнавальна самостійність у даному випадку займає практичну спрямованість.

3. Використання декількох можливих способів розв'язання завдань, вміння їх комбінувати в пошуках оптимального варіанта для тієї чи іншої ситуації. Можливості для розвитку такого рівня самостійності створюються в умовах організації частково-пошу- кової навчально-пізнавальної діяльності, яка формує творче мислення.

4. Вивчення теоретичних знань як інструменту наукового пізнання, яке виконує включення студента в професійну науково-дослідну діяльність.

До основних видів самостійної роботи студентів, які використовуються у вузах, доцільно віднести:

- доповіді і виступи на семінарах і конференціях;

- виконання науково-дослідних завдань як вищої форми самостійної роботи;

- виконання окремих завдань на лекційних та семінарських заняттях;

- роботу в предметних наукових гуртках та клубах за інтересами;

- роботу з навчальними і контролюючими програмами на комп'ютері;

- виконання практичних та лабораторних робіт;

- індивідуальну роботу з навчальною та методичною літературою;

- участь в олімпіадах, студентських конференціях;

- узагальнення матеріалу під час підготовки до екзамену.

Передовий педагогічний досвід показує, що вже на першому курсі студенти можуть і повинні бути залучені до всіх видів самостійної роботи. Методичне забезпечення індивідуальної і колективної навчально-пізнавальної діяльності пропонує реалізацію принципу проблемності - від лекцій проблемного характеру до включення проблемних ситуацій у питання модульного контролю та екзаменаційних тестових завдань. Основним призначенням проблемних лекцій $€$ моделювання протиріч, які складають основу змісту навчальної дисципліни, залучення студентів до аналізу варіантів вирішення цих протиріч, яке сприяє формуванню творчого теоретичного мислення.

Семінарські заняття організовуються на основі різноманітних форм співробітництва студентів і викладачів, зокрема це дискусії і диспути, в процесі яких студенти шукають аргументи, якіпідтверджують або відкидають трактування даних питань, спонукають їх довироблення власної позиціїі високоїактивності в їїзахисті.

Формуванню самостійності, творчого пошуку сприяють і лабораторні заняття, які передбачають створення і розв'язання екстремальних практичних ситуацій або їх моделей, у процесі яких розвивається професійна інтуїція, вміння орієнтуватися в нестандартних ситуаціях, прогнозувати їх хід, використовуючи завдання різної складності, що забезпечують диференціацію навчально-пізнавальної діяльності.

Необхідним компонентом самостійної роботи студентів є самопідготовка до навчальних занять, мо- 
дульного контролю, практичних занять, яка включає роботу 3 навчальною та науковою літературою, виконання різноманітних письмових індивідуальних завдань, контрольних запитань, тестових завдань. Це дає можливість сформувати у студентів навички організації самостійної роботи 3 джерелами літературної та комп'ютерної інформації.

Вирішення проблем організації самостійної роботи студентів передбачає чіткий і оперативний контроль за самостійною роботою студентів, який проводиться систематично.

Отже, запропонований комплекс заходів щодо організації самостійної роботи студентів дозволяє забезпечити поєднання аудиторної та позааудиторної форм самостійної роботи студентів, диференціювати та індивідуалізувати навчання студентів, забезпечити рівень засвоєння знань, вмінь, навичок, необхідних для реалізації здійснення самостійної діяльності в професійній підготовці, повсякденному житті, в суспільній роботі. Правильно організована систематична самостійна робота студентів над навчальними предметами й надійний та ефективний контроль за нею з боку викладачів і самоконтроль з боку студентів дозволяють вирішити завдання вищої школи

\section{Лiтература}

1. Вергасов В. Д. Активизация познавателььой деятельности студентов в высшей школе / В. Д. Вергасов. - К. : Вища школа, 1985. - 175 с.

2. Еднак В. Основи організації самостійної роботи студентів факультету фізичного виховання / В. Еднак // Наукові записки ТДПУ. Серія: Педагогіка. - 2002. - № 3. С. 128-131.

3. Журавська Л. М. Концептуальні умови управління самостійною роботою студентів у вищих навчальних зак-
- сформувати у студентів науковий світогляд, систему сучасних професійних знань, а також розвинути творчі здібності.

Висновки: 1. Проблема розвитку пізнавальної самостійності студентів є однією з найбільш актуальних в педагогічній теорії і практиці.

2. Об' єктивна можливість розвитку пізнавальної самостійності зумовлена діалектичним характером навчального процесу.

3. Як одна 3 властивостей навчальної діяльності студента пізнавальна самостійність характеризується динамічним взаємозв' язком мотиваційного, змістовного і організаційно-процесуального компонентів.

4. Пізнавальна самостійність у навчанні виявляється різноплановою; у процесі формування всебічно розвиненої особистості - як мета навчання; у процесі засвоєння знань, умінь і навичок - як засіб підвищення усвідомленості та дієвості засвоєного матеріалу.

5. Для успішного розвитку пізнавальної самостійності студентів необхідно формувати в них пізнавальні потреби, розвивати бажання й уміння працювати самостійно, наполегливо добиватись результатів виконання самостійних завдань.

ладах / Л. М. Журавська // Освіта і управління. - 1999. T. 3, № 2. - С. 105-115.

4. Козаков В. А. Самостоятельная работа студентов и ее информационно-методическое обеспечение / В. А. Козаков. - К. : Вища школа, 1990. -247 с.

5. Ярмаченко М. Д. Важливий етап у розвитку педагогічної науки / М. Д. Ярмаченко // Вісник АПН України. - 1993. -№ 1. - С. 8-10. 